\title{
PEMBELAJARAN IPS DI SEKOLAH DASAR BERBASIS PEMBELAJARAN TEMATIK
}

\section{Targana Adi Saputra}

\begin{abstract}
Abstrak
endekatan pembelajaran tematik dalam IPS sering disebut dengan pendekatan interdisipliner. Model pembelajaran tematik pada hakikatnya merupakan suatu sistem pembelajaran yang memungkinkan peserta didik baik secara individual maupun kelompok aktif mencari, menggali, dan menemukan konsep serta prinsip-prinsip secara

IImu Pengetahuan Sosial (IPS) merupakan integrasi dari berbagai cabang ilmu-ilmu sosial seperti: sosiologi, sejarah, geografi, ekonomi, politik, hukum, dan budaya. Ilmu Pengetahuan Sosial dirumuskan atas dasar realitas dan fenomena sosial yang mewujudkan satu pendekatan interdisipliner dari aspek dan cabang-cabang ilmu-ilmu sosial (sosiologi, sejarah, geografi, ekonomi, politik, hukum, dan budaya). IPS atau studi sosial itu merupakan bagian dari kurikulum sekolah yang diturunkan dari isi materi cabang-cabang ilmu-ilmu sosial: sosiologi, sejarah, geografi, ekonomi, politik, antropologi, filsafat, dan psikologi sosial. Sejalan dengan konsep tersebut, pembelajaran tematik dalam IPS adalah model pembelajaran yang pengembangannya dimulai dengan menentukan topik tertentu sebagai tema atau topik sentral, setelah tema ditetapkan maka selanjutnya tema itu dijadikan dasar untuk menentukan dasar sub-sub tema dari bidang studi lain yang terkait.
\end{abstract} holistik dan otentik.

Kata Kunci : Pembelajaran Tematik , IPS 


\section{PENDAHULUAN}

Sesuai dengan tahapan perkembangan anak, karakteristik cara anak belajar, konsep belajar dan pembelajaran bermakna, kegiatan pembelajaran bagi anak kelas awal SD sebaiknya dilakukan dengan pembelajaran tematik. Pembelajaan tematik adalah pembelajaran terpadu yang menggunakan tema untuk mengaitkan beberapa mata pelajaran sehingga dapat memberikan pengalaman bermakna kepada siswa.

Model pembelajaran tematik merupakan model pembelajaran yang pengembangannya dimulai dengan menentukan topik tertentu sebagai tema atau topik sentral, setelah tema ditetapkan maka selanjutnya tema itu dijadikan dasar untuk menentukan dasar sub-sub tema dari bidang studi lain yang terkait (Fogarty, 1991 : 54). Depdiknas (2007a: 5) menyatakan bahwa pembelajaan tematik adalah pembelajaran tepadu yang menggunakan tema untuk mengaitkan beberapa mata pelajaran sehingga dapat memberikan pengalaman bermakna kepada siswa.

Sejalan dengan pendapat di atas, Sa'ud (2006:5) menyatakan bahwa pembelajaran terpadu adalah sebuah pendekatan dalam pembelajaran sebagai suatu proses untuk mengaitkan dan memadukan materi ajar dalam satu mata pelajaran atau antar mata pelajaran dengan semua aspek perkembangan siswa, kebutuhan dan minat anak, serta kebutuhan dan tuntutan lingkunga sosial.

Selanjutnya pelaksanaan pembelajaran dengan memanfaatkan tema akan diperoleh beberapa manfaat yaitu:

(1) dengan menggabungkan beberapa kompetensi dasar dan indikator serta isi mata pelajaran akan terjadi penghematan, karena tumpang tindih materi dapat dikurangi bahkan dihilangkan; (2) siswa mampu melihat hubungan-hubungan yang bermakna sebab isi/materi pembelajaran lebih berperan sebagai sarana atau alat, bukan tujuan akhir;(3) pembelajaran menjadi utuh sehingga siswa akan mendapat pengertian mengenai proses dan materi yang tidak terpecah-pecah; dan (4) dengan adanya pemaduan antar mata pelajaran maka penguasaan konsep akan semakin baik dan meningkat (Depdiknas 2007a: 6).

Berdasarkan pengertian di atas, pembelajaran tematik adalah pembelajaran yang dirancang berdasarkan tema-tema tertentu. Dalam pembahasannya tema itu ditinjau dari berbagai mata pelajaran. Sebagai contoh, tema "jenis pekerjaan" dapat ditinjau dari mata pelajaran IPS, matematika, IPA, bahasa, dan seni. Pembelajaran tematik menyediakan keleluasan dan kedalaman implementasi kurikulum, menawarkan kesempatan yang sangat banyak pada siswa untuk memunculkan dinamika dalam pendidikan. Unit tematik adalah epitome dari seluruh bahasan pembelajaran yang memfasilitasi siswa untuk secara produktif menjawab pertanyaan yang dimunculkan sendiri dan memuaskan rasa ingin tahu dengan penghayatan secara alamiah tentang dunia di sekitar mereka.

Pendekatan pembelajaran tematik dalam IPS sering disebut dengan pendekatan interdisipliner. Model pembelajaran tematik pada hakikatnya merupakan suatu sistem pembelajaran yang memungkinkan peserta didik baik secara individual maupun kelompok aktif mencari, menggali, dan menemukan konsep serta prinsip-prinsip secara holistik dan otentik (Depdikbud, 1996:3). Salah satu di antaranya adalah memadukan Kompetensi Dasar. Melalui pembelajaran termatik peserta didik dapat memperoleh pengalaman langsung, sehingga dapat menambah kekuatan untuk menerima, menyimpan, dan memproduksi kesan-kesan tentang hal-hal yang dipelajarinya. Dengan demikian, peserta didik terlatih untuk dapat menemukan sendiri berbagai konsep yang dipelajari.

Pada pendekatan pembelajaran termatik, program pembelajaran disusun dari berbagai cabang ilmu dalam rumpun ilmu sosial. Pengembangan pembelajaran termatik dalam hal ini, dapat mengambil suatu topik dari suatu cabang ilmu tertentu, kemudian dilengkapi, dibahas, diperluas, dan diperdalam dengan cabang-cabang ilmu yang lain. Topik/tema dapat dikembangkan dari isu, peristiwa, dan permasalahan 
yang berkembang. Bisa membentuk permasalahan yang dapat dilihat dan dipecahkan dari berbagai disiplin atau sudut pandang, contohnya banjir, pemukiman kumuh, potensi pariwisata, IPTEK, mobilitas sosial, modernisasi, revolusi yang dibahas dari berbagai disiplin ilmu-ilmu sosial

\section{MODEL PEMBELAJARAN IPS TERPADU}

Beberapa model penerapan pendekatan tematik/terpadu internal dalam pembelajaran IPS dapat dikategorikan sebagai berikut.

\section{Model Integrasi Berdasarkan Topik}

Dalam pembelajaran IPS keterpaduan dapat dilakukan berdasarkan topik yang terkait, misalnya 'Kegiatan ekonomi penduduk'. Kegiatan ekonomi penduduk dalam yang dikembangkan dan ditinjau dari berbagai disiplin ilmu yang tercakup dalam IPS. Kegiatan ekonomi penduduk dalam hal ini ditinjau dari persebaran dan kondisi fisis-geografis yang tercakup dalam disiplin Geografi. Secara sosiologis, Kegiatan ekonomi penduduk dapat mempengaruhi interaksi sosial di masyarakat atau sebaliknya. Secara historis dari waktu ke waktu kegiatan ekonomi penduduk selalu mengalami perubahan. Selanjutnya penguasaan konsep tentang jenis-jenis kegiatan ekonomi sampai pada taraf mampu menumbuhkan krteatifitas dan kemandirian dalam melakukan tindakan ekonomi dapat dikembangkan melalui kompetensi yang berkaitan dengan ekonomi.

\section{Model Integrasi Berdasarkan Potensi Utama}

Keterpaduan IPS dapat dikembangkan melalui topik yang didasarkan pada potensi utama yang ada di wilayah setempat; sebagai contoh, "Potensi Bali Sebagai Daerah Tujuan Wisata". Dalam pembelajaran yang dikembangkan dalam Kebudayaan Bali dikaji dan ditinjau dari faktor alam, historis kronologis dan kausalitas, serta perilaku masyarakat terhadap aturan. Melalui kajian potensi utama yang terdapat di daerahnya, maka peserta didik selain dapat memahami kondisi daerahnya juga sekaligus memahami Kompetensi Dasar yang terdapat pada beberapa disiplin yang tergabung dalam IPS.

\section{Model Integrasi Berdasarkan Permasalahan}

Model pembelajaran terpadu pada IPS yang lainnya adalah berdasarkan permasalahan yang ada, contohnya adalah "Tenaga Kerja Indonesia". Pada pembelajaran terpadu, Tenaga Kerja Indonesia ditinjau dari beberapa faktor sosial yang mempengaruhinya. Di antaranya adalah faktor geografi, ekonomi, sosiologi, dan historis

\section{PENERAPAN PENDEKATAN TEMATIK DALAM PEMBELAJARAN IPS DI SD}

\section{Tujuan Pembelajaran IPS di Sekolah Dasar}

Tujuan dari proses pendidikan di sekolah dasar adalah agar siswa mampu memahami potensi diri, memiliki peluang, dan memahami tuntutan lingkungan serta dapat merencanakan masa depan mengenai serangkaian keputusan yang paling mungkin bagi dirinya. Tujuan akhir pendidikan dasar adalah diperolehnya pengembangan pribadi anak yang dapat membangun dirinya sendiri dan ikut serta bertanggung-jawab terhadap pembangunan bangsa, mampu melanjutkan ke tingkat pendidikan yang lebih tinggi, dan mampu hidup di masyarakat dan mengembangkan diri sesuai dengan bakat, minat, kemampuan, dan lingkungan. 
Berkaitan dengan tujuan di atas Hasan, (1996: 41) mengemukakan bahwa fungsi dari kurikulum IPS Sekolah Dasar adalah membentuk sikap rasional dan bertanggung jawab terhadap masalah-masalah yang timbul akibat interaksi antara manusia dan lingkungannya. Sementara itu tentang materi pembelajaran dikemukakan Djahiri, (1995: 6) bahwa pengajaran IPS di Sekolah Dasar tidak bersifat pengetahuan. Ini bermakna bahwa yang diajarkan bukanlah teori-teori ilmu sosial, melainkan hal-hal yang praktis yang berguna bagi dirinya dan kehidupannya kini maupun kelak dikemudian hari dalam berbagai lingkungan serta berbagai aspek kehidupannya. Untuk kepentingan itu, pembelajaran IPS di SD harus dimulai dari lingkungan keluarga siswa itu sendiri, lingkungan sekolah dan para tetangga dengan cara membandingkan diantara sesamanya. Hal ini perlu ditekankan untuk memperjelas kebutuhankebutuhan dasar bersama, serta respek-respek yang mengiringinya, yaitu fakta-fakta adanya keaneka ragaman (Mutakin, 2004: 17).

Materi pembelajaran IPS di SD yang syarat dengan konsep, pengertian, dan prinsip-prinsip abstrak, perlu mendapatkan perhatian yang serius agar tujuan pembelajaran lebih bermakna. Kebermaknaan tujuan pembelajaran ini, akan lebih baik dan efektif manakala bahan ajar dan tugas-tugas yang diberikan dirasakan akrab, intim, dan menyentuh diri siswa. Ausebel (Dahar, 1996: 52) menegaskan bahwa kebermaknaan belajar dapat diraih manakala terjadi hubungan substantive aspek konsep-konsep, informasi atau situasi baru dengan komponen yang relevan terdapat dalam struktur dalam diri siswa. Baik dalam hubungan-hubungan yang bersifat derivative, korektif, suportif maupun yang bersifat hubungan-hubungan kualitatif.

Tujuan Pendidikan IPS dalam Permen No. 22 Tahun 2006 tentang Standar Isi dirumuskan secara jelas bahwa tujuan mata pelajaran IPS pada tingkat satuan pendidikan SD/MI adalah:

a. Mengenal konsep-konsep yang berkaitan dengan kehidupan masyarakat dan lingkungannya.

b. Memiliki kemampuan dasar untuk berpikir logis dan kritis, rasa ingin tahu, inquiri, memecahkan masalah dan ketrampilan dalam kehidupan sosial.

c. Memiliki komitmen dan kesadaran terhadap nilai-nilai sosial dan kemanusiaan.

d. Memiliki kemampuan berkomunikasi, bekerjasama dan berkompetisi dalam masyarakat yang majemuk, tingkat lokal, nasional dan global.

NCSS, (1989: 6) secara rinci mengemukakan tujuan Pendidikan Ilmu Pengetahuan Sosial (Social Studies Education) adalah untuk mengembangkan:

a. civic responsibility an active civic participation;

$b$. perspective on their owen life experlences so they see themselves as part of the larger human sdventurein time and place;

c. a critical ndestanding time and plce the history, geography, economic, political, social institution, traditions, and values of the united states as expressed in both their nity and diversity;

d. an understanding of other peoples and the unityand diversty of world history, geography, instition, tradition and values;

e. crtical attitude, and analytical perspective to appropriate to analysis of human condition,

Sejalan dengan tujuan pendidikan IPS yang telah diuraikan di atas, maka pembelajaran IPS yang semestinya dilakukan dalam kegiatan pembelajaran di kelas adalah sebagai berikut.

a. Pembelajaran IPS semestinya diorganisasikan/dipilih secara terpisah sesuai dengan body of knowledge masing-masing disiplin ilmu sosial .

b. Diorganaisir secara ilmiah dan psikologis dan menghendaki agar program pengajaran mengkorelasikan bahkan mungkin harus mengintegrasikan beberapa disiplin ilmu sosial, dalam unit program studi.

c. Tematis dan problem solving 
d. Pembelajaran IPS mempelajari bahan pelajaran yang pantang (tabu) untuk dibicarakan, dengan demikian para siswa akan memperoleh kesempatan untuk memecahkan konflik intra-personal maupun antar-personal.

\section{Pelaksanaan Pembelajaran Tematik IPS di Sekolah Dasar}

Pelaksanaan pembelajaran tematik IPS di sekolah harus didasarkan pada rambu-rambu umum yang dikemukakan Depdiknas (2007a: 7) sebagai berikut.

a. Tidak semua mata pelajaran harus dipadukan;

b. Dimungkinkan terjadi penggabungan kompetensi dasar lintas semester pada kelas yang sama;

c. Kompetensi dasar yang tidak dapat dipadukan, jangan dipaksakan, namun dapat dibelajarkan melalui tema lain maupun disajikan secara tersendiri;

d. Kegiatan pembelajaran ditekankan pada kemampuan membaca, menulis, dan berhitung serta penanaman nilai-nilai moral;

e. Setiap kegiatan pembelajaran hendaknya selalu mempergunakan alat peraga yang sesuai dengan tujuan;

f. Judul maupun jumlah tema yang dipilih atau yang ditentukan oleh masing-masing sekolah, disesuaikan dengan karakteristik siswa, minat, lingkungan, dan daerah setempat;

g. Agar pelaksanaan dapat optimal, jumlah peserta didik disesuaikan dengan jumlah guru di kelas.

Agar kegiatan pembelajaran dengan menggunakan pendekatan tematik berjalan dengan baik, perlu dilakukan beberapa hal yang tercakup dalam dua tahapan yaitu; tahap perencanaan dan tahap pelaksanaan.

\section{a. Perencanaan Pembelajaran Tematik}

Ada beberapa kegiatan yang perlu dilakukan dalam tahap perrencanaan pembelajaran tematik yaitu; pemetaan kompetensi dasar, pengembangan jaringan tema, pengembangan silabus, penyusunan Rencana Pelaksanaan Pembelajaran (RPP).

1) Pemetaan kompetensi dasar

Kegiatan pemetaan kompetensi dasar dilakukan untuk memperoleh gambaran secara menyeluruh dan utuh semua standar kompetensi, kompetensi dasar dan indikator dari berbagai mata pelajaran yang dipadukan dalam tema yang dipilih. Kegiatan yang dilakukan adalah: a). Penjabaran Standar Kompetensi (SK) dan Kompetensi Dasar (KD) ke dalam indikator. b). Menentukan tema, c). Identifikasi dan analisis $\mathrm{SK}, \mathrm{KD}$, dan indikator.

2) Pengembangan jaringan tema.

Pembuatan jaringan tema pada dasarnya adalah kegiatan menghubungkan kompetensi dasar dan indikator dengan tema pemersatu. Dengan jaringan tema tersebut akan terlihat kaitan antara tema, kompetensi dasar dan indikator dari setiap mata pelajaran. Jaringan tema ini dapat dikembangkan sesuai dengan alokasi waktu setiap tema.

3) Pengembangan silabus

Hasil seluruh proses yang telah dilakukan pada tahap-tahap sebelumnya dijadikan dasar dalam penyusunan silabus. Komponen silabus terdiri dari standar kompetensi, kompetensi dasar, indikator, pengalaman belajar, alat/sumber, dan penilaian.

4).Penyusunan Rencana Pelaksanaan Pembelajaran (RPP)

Untuk keperluan pelaksanaan pembelajaran guru perlu menyusun RPP, ini merupakan realisasi dari pengalaman belajar siswa yang telah ditetapkan dalam silabus pembelajaran. 


\section{b. Pelaksanaan Pembelajaran Tematik}

Pelaksanaan pembelajaran tematik setiap hari dilakukan dengan menggunakan tiga tahapan kegiatan yaitu; kegiatan pembukaan/ awal/pendahuluan, kegiatan inti, dan kegiatan penutup. Alokasi waktu untuk setiap tahapan adalah kegiatan pembukaan kurang lebih satu jam pelajaran ( $1 \times 35$ menit), kegiatan inti 3 jam pelajaran ( $3 \times 35$ menit) dan kegiatan penutup satu jam pelajaran ( $1 \times 35$ menit).

1) Kegiatan pembukaan

Kegiatan pembuka dilakukan terutama untuk menciptakan suasana awal pembelajaran untuk mendorong siswa memfokuskan dirinya agar mampu mengikuti proses pembelajaran dengan baik. Sifat dari kegiatan pembukaan adalah kegiatan untuk pemanasan. Pada tahap ini dapat dilakukan penggalian terhadap pengalaman anak tentang tema yang akan disajikan. Sa'ud (2006: 56) mengemukakan bahwa kegiatan pembuka (introduction) pada dasarnya merupakan kegiatan awal yang harus ditempuh guru dan peserta didik pada setiap kali pelaksanaan pembelajaran tematik. Fungsinya terutama untuk menciptakan suasana awal pembelajaran yang efektif yang memungkinkan peserta didik dapat mengikuti proses pembelajaran dengan baik. Efisiensi waktu dalam kegiatan pendahuluan pembelajaran tematik ini perlu diperhatikan. Dalam waktu sekitar 35 menit tersebut, diharapkan guru dapat menciptakan kondisi awal pembelajaran dengan baik, sehingga dalam kegiatan inti pembelajaran tematik peserta didik sudah siap untuk mengikuti pelajaran dengan seksama.

Kegiatan utama yang dilaksanakan dalam pendahuluan pembelajaran ini di antaranya untuk menciptakan kondisi-kondisi awal pembelajaran yang kondusif, melaksanakan kegiatan apersepsi (apperception), dan penilaian awal (pre-test). Penciptaan kondisi awal pembelajaran dilakukan dengan cara: mengecek atau memeriksa kehadiran peserta didik (presence, attendance), menumbuhkan kesiapan belajar peserta didik (readiness), menciptakan suasana belajar yang demokratis, membangkitkan motivasi belajar peserta didik, dan membangkitkan perhatian peserta didik. Beberapa contoh kegiatan yang dapat dilakukan adalah bercerita, kegiatan fisik/jasmani, dan menyanyi.

\section{2) Kegiatan inti}

Kegiatan inti merupakan kegiatan dalam rangka pelaksanaan pembelajaran tematik yang menekankan pada proses pembentukan pengalaman belajar peserta didik (learning experiences). Pengalaman belajar tersebut bisa dalam bentuk kegiatan tatap muka dan nontatap muka. Pengalaman belajar tatap muka dimaksudkan sebagai kegiatan pembelajaran yang dilakukan dengan mengembangkan bentuk-bentuk interaksi langsung antara guru dengan peserta didik, sedangkan pengalaman belajar nontatap muka dimaksudkan sebagai kegiatan belajar yang dilakukan peserta didik dalam berinteraksi dengan sumber belajar lain yang bukan kegiatan interaksi guru-peserta didik. (Sa'ud, 2006: 56)

Kegiatan inti dalam pembelajaran terpadu bersifat situasional, dalam arti perlu disesuaikan dengan situasi dan kondisi tempat proses pembelajaran itu berlangsung. Kegiatan di awal kegiatan inti pembelajaran tematik yaitu menjelaskan alternatif kegiatan belajar yang akan dialami peserta didik. Dalam tahapan ini guru perlu menyampaikan kepada peserta didik tentang kegiatan-kegiatan belajar yang harus ditempuh peserta didik dalam mempelajari tema/topik, atau materi pembelajaran tematik. Kegiatan belajar yang ditempuh peserta didik dalam pembelajaran terpadu lebih diutamakan pada terjadinya proses belajar yang berkadar aktivitas tinggi. Pembelajaran berorientasi pada aktivitas peserta didik, sedangkan guru lebih banyak bertindak sebagai fasilitator yang memberikan kemudahankemudahan kepada peserta didik untuk belajar. Peserta didik diarahkan untuk mencari dan menemukan sendiri apa yang dipelajarinya, sehingga prinsip-prinsip belajar dalam teori konstruktivisme dapat dijalankan.

Dalam membahas dan menyajikan materi/bahan pembelajaran tematik harus diarahkan pada suatu proses perubahan tingkah laku peserta didik. Penyajian bahan pembelajaran harus dilakukan secara 
terpadu melalui penghubungan konsep dari mata pelajaran satu dengan konsep mata pelajaran lainnya. Dalam hal ini, guru harus berupaya menyajikan bahan pelajaran dengan strategi mengajar yang bervariasi, yang mendorong peserta didik pada upaya penemuan pengetahuan baru. Kegiatan pembelajaran terpadu bisa dilakukan melalui kegiatan pembelajaran secara klasikal, kelompok, dan perorangan. (Sa'ud, 2006: 56)

3) Kegiatan penutup

Tahapan terakhir adalah melaksanakan kegiatan penutup. Sifat dari kegiatan penutup adalah untuk menenangkan. Beberapa contoh kegiatan akhir/penutup yang dapat dilakukan adalah menyimpulkan/ mengungkapkan hasil pembelajaran yang telah dilakukan, mendongeng, membacakan cerita dari buku, pantomim, pesan-pesan moral, musik/apresiasi musik.

\section{c. Penilaian Pembelajaran Tematik}

Penilaian dalam pembelajaran tematik adalah suatu usaha untuk mendapatkan berbagai informasi secara berkala, berkesinambungan, dan menyeluruh tentang proses dan hasil dari pertumbuhan dan perkembangan yang telah dicapai oleh anak didik melalui program kegiatan belajar. Objek dalam penilaian pembelajaran terpadu mencakup penilaian terhadap proses dan hasil belajar peserta didik. Penilaian proses belajar adalah upaya pemberian nilai terhadap kegiatan pembelajaran yang dilakukan oleh guru dan peserta didik, sedangkan penilaian hasil belajar adalah proses pemberian nilai terhadap hasil-hasil belajar yang dicapai dengan menggunakan kriteria tertentu. Hasil belajar tersebut pada hakikatnya merupakan pencapaian kompetensi-kompetensi yang mencakup aspek pengetahuan, keterampilan, sikap dan nilai-nilai yang diwujudkan dalam kebiasaan berpikir dan bertindak. Kompetensi tersebut dapat dikenali melalui sejumlah hasil belajar dan indikatornya yang dapat diukur dan diamati. Penilaian proses dan hasil belajar itu saling berkaitan satu dengan lainnya, hasil belajar merupakan akibat dari suatu proses belajar.

Tujuan Penilaian pembelajaran tematik menurut Depdiknas (2007a: 14) adalah sebagai berikut.

a. Mengetahui percapaian indikator yang telah ditetapkan

b. Memperoleh umpan balik bagi guru, untuk pengetahui hambatan yang terjadi dalam pembelajaran maupun efektivitas pembelajaran

c. Memperoleh gambaran yang jelas tentang perkembangan pengetahuan, keterampilan dan sikap siswa

d. Sebagai acuan dalam menentukan rencana tindak lanjut (remedial, pengayaan, dan pemantapan).

Penilaian tematik dilaksanakan sesuai dengan prinsip penilaian tematik Depdiknas (2007a: 14) adalah sebagai berikut:

a. Penilaian di kelas I, II, dan III mengikuti aturan penilaian mata-mata pelajaran lain di sekolah dasar. Mengingat bahwa siswa kelas I SD belum semuanya lancar membaca dan menulis, cara penilaian di kelas I tidak ditekankan pada penilaian secara tertulis.

b. Kemampuan membaca, menulis dan berhitung merupakan kemampuan yang harus dikuasai oleh peserta didik kelas I dan II. Oleh karena itu, penguasaan terhadap ke tiga kemampuan tersebut adalah prasyarat untuk kenaikan kelas. Di kelas III penilaian mulai dilakukan pada penilaian konsep materi pelajaran.

c. Penilaian dilakukan dengan mengacu pada indikator dari masing-masing Kompetensi Dasar (KD) dan Hasil Belajar (HB) dari mata-mata pelajaran.

d. Penilaian dilakukan secara terus menerus dan selama proses belajar mengajar berlangsung, misalnya sewaktu siswa bercerita pada kegiatan awal, membaca pada kegiatan inti dan menyanyi pada kegiatan akhir.

e. Hasil karya/kerja siswa dapat digunakan sebagai bahan masukan guru dalam mengambil keputusan siswa misalnya; penggunaan tanda baca, ejaan kata, maupun angka, serta karya inovasi siswa dalam mata pelajara-pelajaran tertentu. 
Alat penilaian dapat berupa Tes dan Nontes. Tes mencakup; tertulis, lisan, atau perbuatan, catatan harian perkembangan siswa, dan porto folio. Dalam kegiatan pembelajaran di kelas awal penilaian yang lebih banyak digunakan adalah melalui pemberian tugas dan porto folio. Guru menilai anak melalui pengamatan yang lalu dicatat pada sebuah buku bantu. Sedangkan Tes tertulis digunakan untuk menilai kemampuan menulis siswa, khususnya untuk mengetahui tentang; penggunaan tanda baca, ejaan, kata atau angka di kelas I dan II dan penilaian serta konsep untuk di kelas III.

\section{PENUTUP}

Berdasarkan berbagai keunggulan pembelajaran tematik, pembelajaran tematik seharusnya diterapkan di sekolah dasar khususnya kelas rendah. Khusus untuk mata pelajaran IPS, pembelajaran IPS dapat pula dilakukan dengan pendekatan terpadu baik secara internal maupun eksternal.

\section{Daftar Pustaka}

Al Muchtar, (2001). Epistimologi Pendidikan Ilmu Pengetahuan Sosial. Bandung : Gelar Pustaka Mandiri. Banks \& Ambrose, (1990). Teaching Strategies for the Social Studies. New York: Longman.

BSNP. (2006). Model Kurikulum Tingkat Satuan Pendidikan dan Model Silabus Mata Pelajaran SD/MI. Jakarta: BP. Cipta Jaya.

Depdiknas, (2007a). Model Pembelajaran Tematik Kelas Awal SD. Jakarta: Depdiknas.

Depdiknas, (2007b). Model Pembelajaran IPS Terpadu. Jakarta: Depdiknas.

Fogarty, (1991). How to Integrated The Curricula. Palatine: IRI

Hasan, Said, H. (2004). Kurikulum dan Tujuan Pendidikan, Jurnal JPIS. Bandung: Media Komunikasi Antar FPIPS-UPI, FKIP Universitas/STKIP Se-Indonesia.

Mutakin, A. (2004). Konsep Dasar Pengorganisasian Pembelajaran IPS di Sekolah Dasar. Bandung: Bina Siswa

NCCS, (1994)."Curriculum Standar for Social Sudies, Expection for Excelence". Washington: NCCS.

Sa'ud, U.S. (2006). Pembelajaran Terpadu. Bandung: UPI Press

Sapriya, dkk (2003). Strategi Pembelajaran Ilmu Pengetahuan Sosial. Jakarta: Universitas Terbuka. Soemantri, N.M. (2001). Menggagas Pembaharuan Pendidikan IPS. Bandung: Rosdakarya SPs UPI. Sumaatmadja, N. (2001). Metode Pengajaran Ilmu Pengatahuan Sosial. Bandung: Alumni.

\section{BIODATA PENULIS}

Targana Adi Saputra adalah Dosen Program Studi S1 PGSD UPI Kampus Cibiru 